\title{
Modeling the underlying environmental factors of milky sea case and luminous bacteria presence in Java Southern Sea in 2019 Andri Wibowo ${ }^{1 *}$
}

\begin{abstract}
The milky sea is one of the unique natural phenomena caused by the presence of luminous Vibrio bacteria in marine ecosystems. Recently a milky sea has been reported frequently included in the Java Southern Sea. Simultaneously, numerous remote sensing based approaches have been developed to detect the presence of luminous bacteria and the milky sea. Despite this state of the art, the information of detrimental factors of the marine bioluminescence was still limited. Then this research aims to model the underlying environmental factors causing the milky sea and luminous bacteria presence in the Java Southern Sea in 2019. The remote sensing assessment for the period of July 29-August 6, 2019 shows that the magnitude of bioluminescence measured in radiance was having a maximum value of 255 nanoW $/ \mathrm{cm}^{2} / \mathrm{sr}$ and an average of $107 \mathrm{nanoW} / \mathrm{cm}^{2} / \mathrm{sr} / \mathrm{day}$ (95\%CI: 71.9 to $142 \mathrm{nanoW} / \mathrm{cm}^{2} / \mathrm{sr} / \mathrm{day}$ ). The milky sea size increased and reached its peak with a size of $44,124 \mathrm{~km}^{2}$ and then declined. The average milky sea size was $37,942 \mathrm{~km}^{2}$ (95\% CI: 33,400 to $42,500 \mathrm{~km}^{2}$ ) and increased with average rate of $16.01 \%$ (95\% CI: $5.41 \%$ to $26.66 \%$ ). While Akaike Information Criterion (AIC) indicates that the best model to infer the relationship of bacterial bioluminescence with its environmental factors contained Chlorophyll a followed by sea surface temperature factors with $\mathrm{AIC}_{\mathrm{c}}$ values of 101.16 ( $\mathrm{AIC}_{\text {weight }}$ : 0.50) and 101.95 ( $\left.\mathrm{AIC}_{\text {weight }}: 0.34\right)$. This indicates that low temperature and high plankton cells is the limiting factors of the bacterial bioluminescence.
\end{abstract}

Keywords: AIC, bioluminescence, Chlorophyll, Java Southern Sea, Vibrio

\footnotetext{
${ }^{1}$ Ecol. Lab., Fac. of Math.s and Nat.Sci., Univ. Indonesia, 16424, Depok, West Java, Indonesia

*Email: andriwibowocbc@gmail.com
}

\section{Introduction}

In nature, organism mainly microorganism has the ability to emit the light. This ability is known as bioluminescence. This bioluminescence was also observed in aquatic ecosystems including in marine ecosystems. Bioluminescence is a result of the biochemistry reaction of organisms involving the oxidation of an aliphatic aldehyde by a reduced flavin mononucleotide. The products of this oxidation reaction include an oxidized flavin mononucleotide, a fatty acid chain, and energy in the form of a bluegreen visible light. The bioluminescence process was as follows: $\mathrm{FMNH}_{2}+\mathrm{O}_{2}+\mathrm{RCHO} \rightarrow \mathrm{FMN}+$ $\mathrm{RCOOH}+\mathrm{H}_{2} \mathrm{O}+$ light (Fisher et al. 1996, Willes et al. 2005, Gregor et al. 2018). The purpose of bioluminescence is to attract prey or even more complicated. In bacteria, bioluminescence functions to attract and lure other organisms to prey on bacteria (Zarubin et al. 2012).

There are wide ranges of marine microorganisms that can emit lights, including bacteria. In bacteria, bioluminescence occurs as a continuous glow in the presence of oxygen at cell concentrations exceeding quorum-sensing levels. Luminous bacteria were occurring as free-living microorganisms in seawater, in symbiotic associations with marine organisms (most notably fish and squids), as saprophytes on suspended organic material such as marine snow, as a major component of fecal pellets, and as parasites on crustaceans (Nelson \& Hastings 1979, Ruby et al. 1979, Dworkin et al. 2006, Andrew et al. 1984). Among several bioluminescent bacteria species inhabiting marine ecosystems, there are species of interest including members of Vibrio genera. The bacterial bioluminescence is characterized by its continuous light emission that can persist for many days under appropriate conditions.

A bioluminescence activity if happens in the sea will be appeared as milky sea due to the layer of whitish light expanding more than $1 \mathrm{~km}^{2}$ in the surface of the water. Recently the detection of the milky sea and bacterial bioluminescence has received attentions. The study was focused on the development of low light sensor that can detect bioluminescence. The most prominent studies on luminous detection were using satellite observation and Visible Infrared Imager Radiometer Suite. Using this method, Miller et al. 
(2005) has identified bacterial bioluminescence in the northwestern Indian Ocean spanning over an area sizing 15,400 $\mathrm{km}^{2}$ and glow over 3 consecutive nights with emission spectra give peak values at $490 \mathrm{~nm}$ and half-bandwidths of $70 \mathrm{~nm}$. Vibrio fischeri strains whose emission spectra are representative of the luminous bacteria species thought to be responsible for milky seas. Recently, bioluminescence has been identified in several locations including in the Java Southern Sea in recent 2019 (Miller et al. 2021). Despite current detection of milky sea in the Java Southern Sea, information on determinant environmental factors causing the presence of milky sea and bacterial bioluminescence in Java Southern Sea is still limited. Then this study aims to model the underlying environmental factors of the milky sea and luminous bacteria presences in the Java Southern Sea in 2019.

\section{Methodology}

Study area

The observed area was the Java Southern Sea located on the South of Java Island. The observation period was from 29 July 2019 to 6 August 2019. During this period, several parameters were retrieved using satellite imagery including the presence of the milky sea measured in, sea surface temperature/SST $\left({ }^{0} \mathrm{C}\right)$, and Chlorophyll a contents $\left(\mathrm{mg} / \mathrm{m}^{3}\right)$.

\section{Bioluminescence detection}

The presence of milky sea and bacterial luminescence were measured as radiance denoted as nanoW $/ \mathrm{cm}^{2} / \mathrm{sr}$. The radiance was measured followed Baugh et al. (2013). The platforms to detect bioluminescence were the Day/Night Band (DNB) parts of the Visible Infrared Imaging Radiometer Suite carried on National Oceanic and Atmospheric Administration operational satellites. This satellite covers regions between latitude of $-65^{\circ}$ South and $+75^{\circ}$ North and produce versatile nighttime images. Monthly composites of those 16-bit images processed by the National Centers for Environmental Information, National Oceanic and Atmospheric Administration were used to detect luminescence with spatial resolution of 15 arc second, equivalent to approximately $0.5 \mathrm{~km}$ on the equator (Hillger et al. 2014, Román et al. 2018, Priyatikanto et al. 2019).

\section{Sea surface temperature}

The sea surface temperature (SST) model of Java Southern Sea for a period of 29 July-6 August 2019 was developed using a method followed Martin et al. (2012). The SST is developed upon the Group for High Resolution Sea Surface Temperature SST used wavelets as basic functions in an optimal interpolation approach on a global 0.011 degree grid. This method is based upon observations from several instruments including the NASA Advanced Microwave Scanning Radiometer-EOS and the Moderate Resolution Imaging Spectroradiometer on the NASA Aqua and Terra platforms.

\section{Chlorophyll a content}

Chlorophyll a contents in Java Southern Sea was measured and mapped based on Terra Moderate Resolution Imaging Spectroradiometer and method followed Ghanea et al. (2015). Terra Moderate Resolution Imaging Spectroradiometer with a spatial resolution of $1 \mathrm{~km}$ were downloaded from NASA data archive and processed to L3 products. The data were composites from a period of 29 July6 August 2019 that has been processed according to the following algorithm:

$\mathrm{C}_{\mathrm{a}}=10^{0.283-2.753 \mathrm{R}+1.457 \mathrm{R} 2+0.659 \mathrm{R} 3-1.403 \mathrm{R} 4}$, with $A=\log 10\left(\frac{\operatorname{Rrs} 443}{\operatorname{Rrs} 550}>\frac{\operatorname{Rrs} 490}{\operatorname{Rrs} 550}\right)$

Where $C_{a}$ is the concentration of Chlorophyll a denoted as $\mathrm{mg} / \mathrm{m}^{3}, \mathrm{R}$ is the reflectance ratio, and Rrs is the remote sensing reflectance (Alianto \& Hamuna 2020). 
Statistical analysis aims to assess the underlying factors causing the presence of bioluminescence. The method used was Principal Component Analysis to determine the correlations and best model of bioluminescence with the underlying factors including SST and Chlorophyll a. The models were validated using Akaike Information Criterion (AIC).

\section{Results and Discussions}

\section{Bioluminescence detection}

The results of bacterial bioluminescence detection using Visible Infrared Imaging Radiometer Suite sensors for a period of July 29-August 6 were available in Figure 1. It is obvious that the appearance of milk sea and bioluminescence in the Java Southern Sea was started on July 29 appeared in West then it was gradually increased in radiance and size (Figure 2). The magnitude of bioluminescence measured in radiance was having a maximum value of $255 \mathrm{nanoW} / \mathrm{cm}^{2} / \mathrm{sr}$ and an average of $107 \mathrm{nanoW} / \mathrm{cm}^{2} / \mathrm{sr} / \mathrm{day}$ (95\%CI: 71.9 to 142 nanoW/cm²/sr/day). The bioluminescence was declining after 9 days or on August 6 . The size of milky sea increased and reached its peak with a size of $44,124 \mathrm{~km}^{2}$ and then declined. The average milky sea size was $37,942 \mathrm{~km}^{2}$ (95\% CI: 33,400 to $42,500 \mathrm{~km}^{2}$ ). For 9 days from July 29 to August 6, the size of the milky sea in the Java Southern Sea increased on an average of $16.01 \%$ (95\%CI: $5.41 \%$ to $26.66 \%$ ). On August 6, East parts of milky sea were reduced.
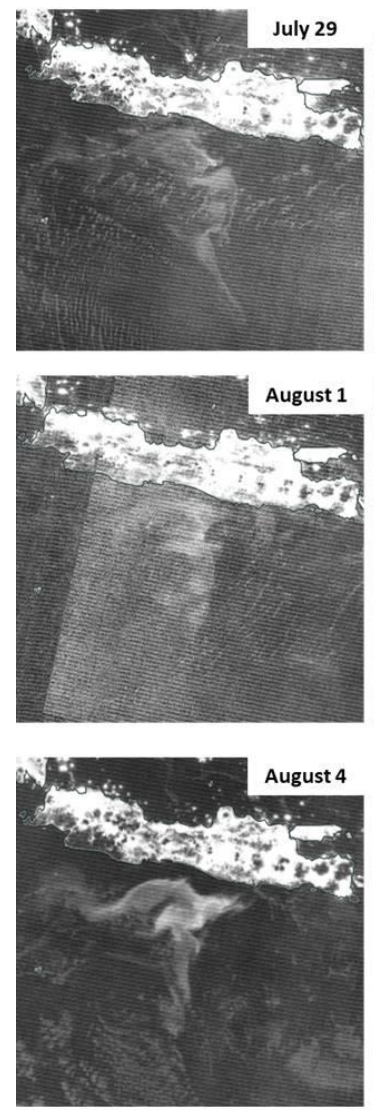
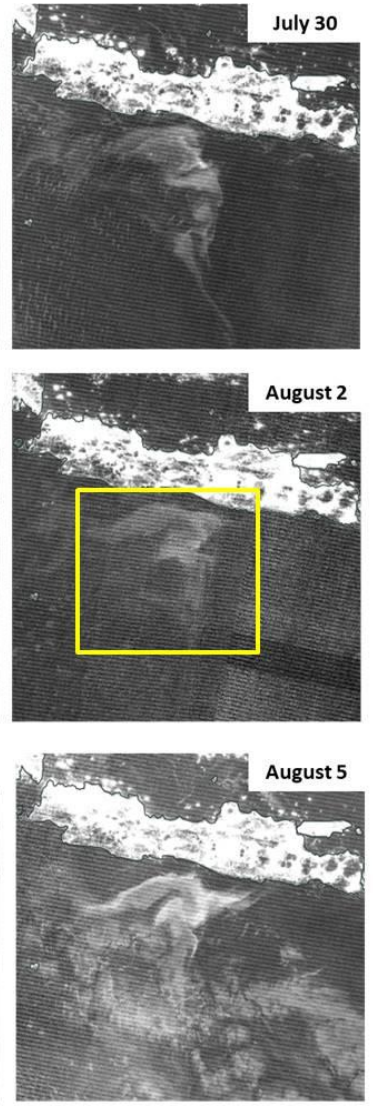

Bioluminescence radiance
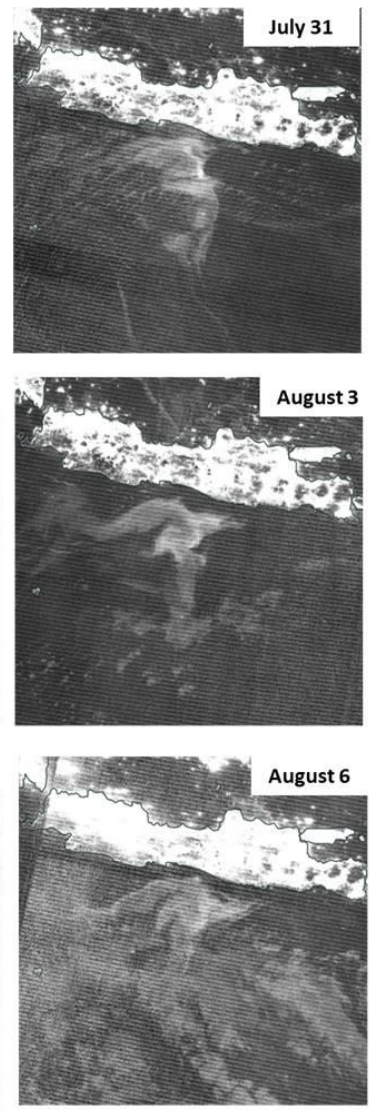
Figure 1. Patterns and appearances of milky sea and bacterial bioluminescence radiance (yellow square and denoted as nanoW/cm $/ \mathrm{sr}$ ) in the Java Southern Sea for period of July 29-August 6, 2019 (Source: Visible Infrared Imaging Radiometer Suite).
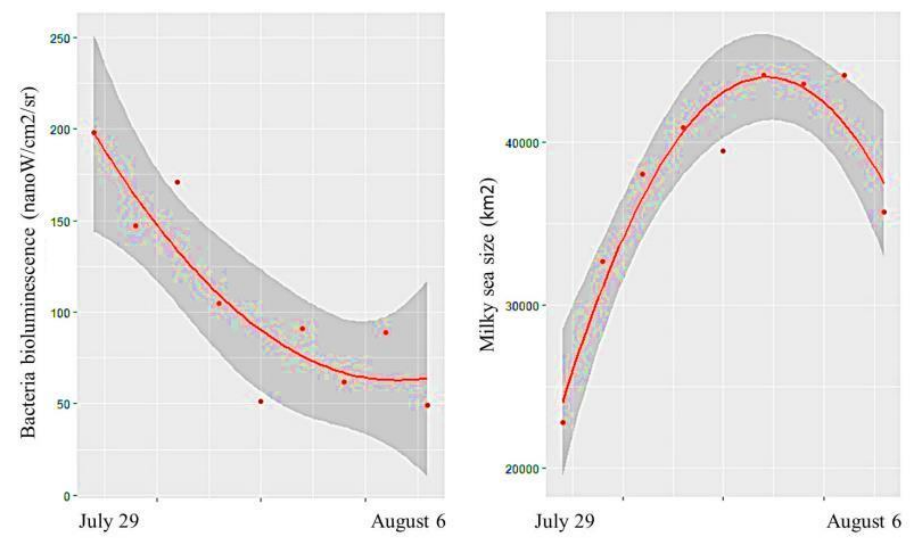

Figure 2. Trends with $95 \% \mathrm{CI}$ of bacterial bioluminescence radiance (left, nanoW/ $/ \mathrm{cm}^{2} / \mathrm{sr}$ ) and size of milky sea (right, $\mathrm{km}^{2}$ ) in the Java Southern Sea for period of July 29-August 6, 2019.
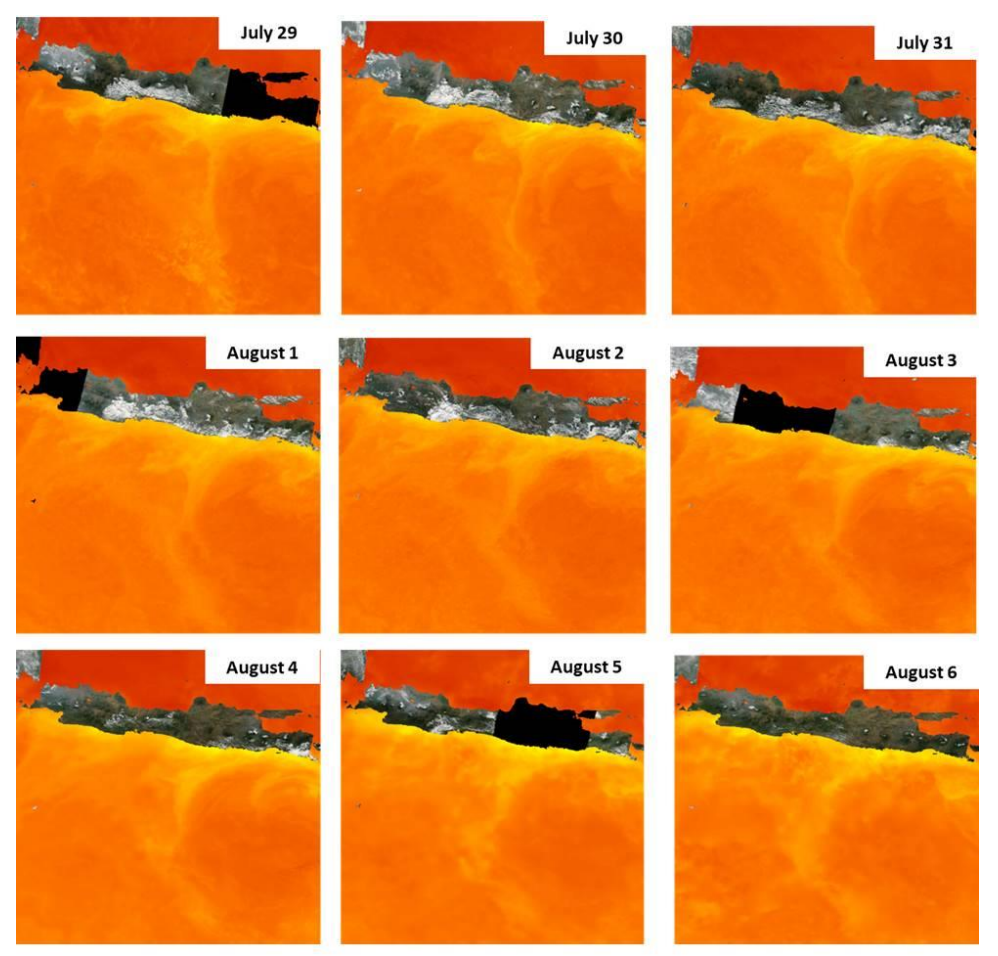

Sea Surface Temperature

Figure 3. Patterns of sea surface temperature/SST $\left({ }^{0} \mathrm{C}\right)$ in the Java Southern Sea for period of July 29August 6, 2019 (Source: the Group for High Resolution Sea Surface Temperature). 
The sea surface temperature (SST) of Java Southern Sea has an average of $24.6{ }^{\circ} \mathrm{C}$ (95\%CI: 24.2 to 25 $\left.{ }^{0} \mathrm{C}\right)$. It is apparent that the water of the Java Southern Sea was warmer whereas there were parts of the Java Southern Sea that has lower SST. This area was observed in the central of Java Southern Sea (Figure 3). In comparison to milky sea presences, the bioluminescence radiance was not presented in the water that has lower SST. Whereas, bioluminescence radiance was observed high in parts of the Java Southern Sea that have high SST. This fact is also supported by the linear trends of bioluminescence radiance with SST (Figure 4). It was apparent that on August 6 the size of water that has lower temperature increased and expanded to the West and reduced the size of the milky sea. The average Chlorophyll a in Java Southern Sea was $0.626 \mathrm{mg} / \mathrm{m}^{3}$ (95\%CI: 0.528 to $0.712 \mathrm{mg} / \mathrm{m}^{3}$ ) (Figure 5). Bioluminescence radiance was observed high in parts of the Java Southern Sea that has low Chlorophyll a. This means that increase in Chlorophyll a will reduce the bioluminescence radiance.
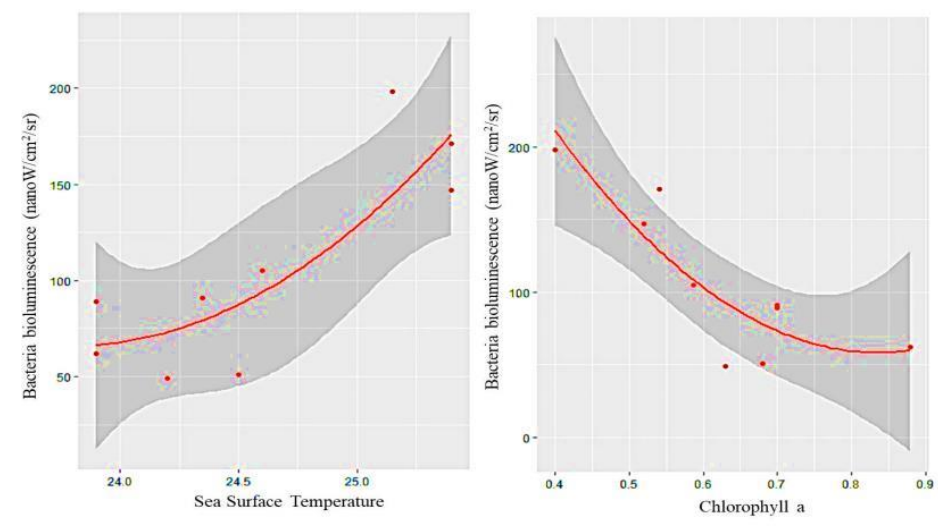

Figure 4. Trends with $95 \% \mathrm{CI}$ of bacterial bioluminescence radiance (nanoW/cm $/ \mathrm{sr}$ ) with SST (left, ${ }^{0} \mathrm{C}$ ) and Chlorophyll a (right, $\mathrm{mg} / \mathrm{m}^{3}$ ) in the Java Southern Sea for period of July 29-August 6, 2019.
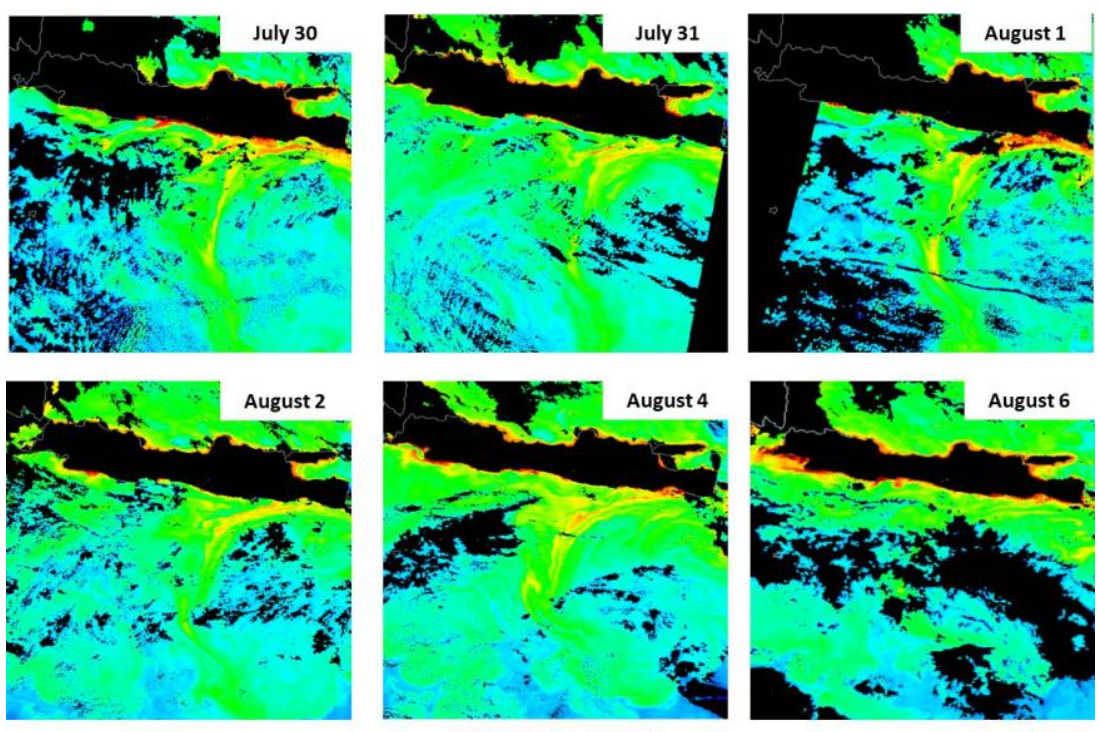

Chlorophyll a $(\mathrm{mg} / \mathrm{m} 3)$

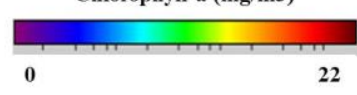

Figure 5. Patterns of Chlorophyll a $\left(\mathrm{mg} / \mathrm{m}^{3}\right)$ in the Java Southern Sea for period of July 30 - August 6, 2019 (Source: the Group for High Resolution Sea Surface Temperature). 


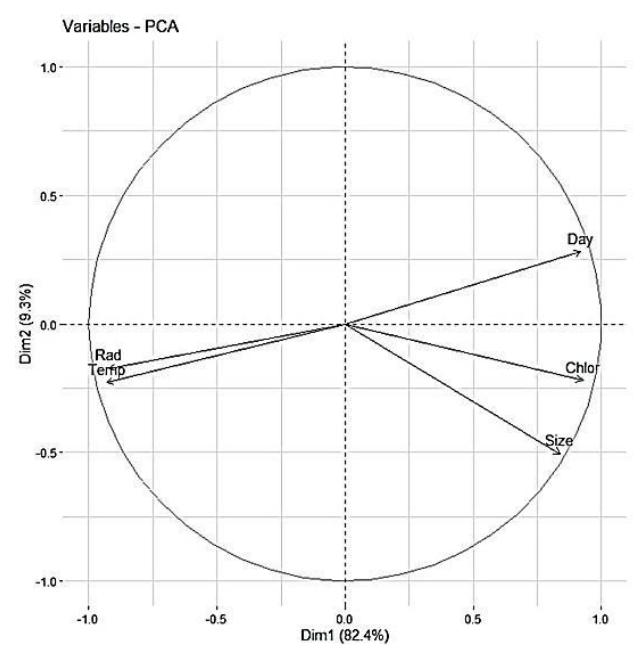

Figure 6. PCA of bacterial bioluminescence (Rad), milky sea size (Size), with Chlorophyll a (Chlor), temperature (Temp), and days (Day) in the Java Southern Sea for period of July 30 - August 6, 2019.

Table 1. Akaike Information Criterion (AIC) attributes for selected models of bacterial bioluminescence (B), Chlorophyll a (C), temperature (T), and days (D).

\begin{tabular}{lrrrlll}
\hline \multicolumn{1}{c}{ Model } & \multicolumn{1}{c}{$\mathrm{K}$} & $\mathrm{AIC}_{\mathrm{c}}$ & \multicolumn{1}{c}{$\Delta \mathrm{AIC}$} & \multicolumn{1}{c}{$\mathrm{AIC}_{\text {weight }}$} & Cum.weight & Log Likehood \\
\hline $\mathrm{B} \sim \mathrm{C}+\mathrm{D}$ & 4 & $101.16^{*}$ & 0.00 & 0.50 & 0.50 & -41.58 \\
$\mathrm{~B} \sim \mathrm{T}+\mathrm{D}$ & 4 & $101.95^{*}$ & 0.79 & 0.34 & 0.84 & -41.98 \\
$\mathrm{~B} \sim \mathrm{C}+\mathrm{T}$ & 4 & 103.42 & 2.26 & 0.16 & 1.00 & -42.71 \\
$\mathrm{~B} \sim \mathrm{C}+\mathrm{D}+\mathrm{T}$ & 5 & 113.12 & 11.95 & 0.00 & 1.00 & -41.56 \\
\hline
\end{tabular}

* Best model

Model of milky sea and bacterial bioluminescence

PCA has confirmed that the high temperature and low Chlorophyll a were correlated with high bacterial bioluminescence. While Akaike Information Criterion (AIC) indicates that the best model to infer the relationship of bacterial bioluminescence contained Chlorophyll a followed by temperature factors with $\mathrm{AIC}_{\mathrm{c}}$ values of 101.16 ( $\mathrm{AIC}_{\text {weight: }}$ 0.50) and 101.95 ( $\mathrm{AIC}_{\text {weight }}$ 0.34). The positive correlation of luminous bacteria with sea surface temperature is in agreement with other results (Fukui et al. 2010, Johnson et al. 2010, Baker-Austin et al. 2016, Montánchez et al. 2019). While inverse relationships of plankton represented by Chlorophyll a with bacterial bioluminescence were also have been reported. Some plankton species were known can release anti bacterial substances that can limit bacteria growth. Taufik et al. (1996) has confirmed that Thalassiosira plankton can reduce the density of luminous $V$. harveyi from $8.9 \times 10^{4}$ to $4.3 \times 10^{4}$. This inverse effect of Thalassiosira on $V$. harveyi explains low bacterial bioluminescence when Chlorophyll a was high.

\section{Conclusion}

Milky sea and bacterial bioluminescence in Java Southern Sea were presented for 9 days. The size of milky sea and bacterial bioluminescence presence were limited by the low SST and high Chlorophyll a. 


\section{References:}

Alianto, Hamuna B. 2020. Spatial-Temporal Variability of Chlorophyll-a Concentration in Cenderawasih Bay and Surrounding Waters. Journal Of Applied Geospatial Information 4(2).

Andrews CC, Karl DM, Small LF, Fowler SN. 1984. Metabolic activity and bioluminescence of oceanic fecal pellets and sediment trap particles. Nature. 307:539-540.

Baker-Austin C, Triñanes J, González-Escalona N, Martinez-Urtaza J. 2016. Non-Cholera Vibrios: The Microbial Barometer of Climate Change. Trends in Microbiology. 25. 10.

Baugh K, Hsu FC, Elvidge C, Zhizhin M. 2013. Nighttime Lights Compositing Using the VIIRS DayNight Band: Preliminary Results. Proceedings of the Asia-Pacific Advanced Network. 35. 70-86.

Dworkin M, Falkow S, Rosenberg E, Schleifer K-H, Stackebrandt EDunlap PV, Kita-Tsukamoto K . 2006. in The Prokaryotes, eds Dworkin M, Falkow S, Rosenberg E, Schleifer K-H, Stackebrandt E (Springer, New York), 3rd Ed. 2: 863-892.

Fisher AJ, Thompson TB, Thoden JB, Baldwin TO, Rayment I. 1996. The 1.5- ̊ Resolution Crystal Structure of Bacterial Luciferase in Low Salt Conditions. Journal of Biological Chemistry. 271 (36): 21956-21968.

Fukui Y, Saitoh S, Sawabe T. 2010. Environmental determinants correlated to Vibrio harveyi-mediated death of marine gastropods. Environ Microbiol. 12(1):124-33.

Ghanea M, Moradi M, Kabiri K. 2015. Investigation the Behavior of MODIS Ocean Color Products under the 2008 Red Tide in the Eastern Persian Gulf. ISPRS - International Archives of the Photogrammetry, Remote Sensing and Spatial Information Sciences. XL-1-W5. 10.5194/isprsarchivesXL-1-W5-227-2015.

Gregor C, Gwosch KC, Sahl SJ, Hell SW. 2018. Enhanced bacterial bioluminescence for imaging Proceedings of the National Academy of Sciences. 115(5): 962-967.

Hillger D, Seaman C, Liang C, Miller S, Lindsey D, Kopp T. 2014. Suomi NPP VIIRS imagery evaluation. Journal of Geophysical Research: Atmospheres, 119(11): 6440-6455.

Johnson CN, Flowers AR, Noriea NF 3rd, Zimmerman AM, Bowers JC, DePaola A, Grimes DJ. 2010. Relationships between environmental factors and pathogenic Vibrios in the Northern Gulf of Mexico. Appl Environ Microbiol. 76(21):7076-84.

Martin M, Dash P, Ignatov A, Banzon V, Helen B, et al. 2012. Group for High Resolution SST (GHRSST) Analysis Fields Inter-Comparisons: Part 1. A GHRSST Multi-Product Ensemble (GMPE). Deep Sea Research Part II Topical Studies in Oceanography. 77-80. 21-30.

Miller S, Haddock S, Elvidge C, Lee T. 2005. Detection of a bioluminescent milky sea from space. Proceedings of the National Academy of Sciences of the United States of America. 102. 14181-4. 10.1073/pnas.0507253102.

Miller SD, Haddock SHD, Straka WC. 2021. Honing in on bioluminescent milky seas from space. Sci Rep. 11: 15443 (https://doi.org/10.1038/s41598-021-94823-z

Montánchez I, Ogayar E, Plágaro AH. 2019. Analysis of Vibrio harveyi adaptation in sea water microcosms at elevated temperature provides insights into the putative mechanisms of its persistence and spread in the time of global warming. Sci Rep 9, 289.

Nealson KH, Hastings JW. 1979. Bacterial bioluminescence: Its control and ecological significance. Microbiol. Rev. 43:496-518.

Priyatikanto R, Admiranto AG, Putri GP, Elyyani, Maryam S, Suryana N. 2019. Map of Sky Brightness over Greater Bandung and the Prospect of Astro - Tourism. Indonesian Journal of Geography 51(2): 190-198.

Román MO, Wang Z, Sun Q, Kalb V, Miller SD, Molthan A et al. 2018. NASA's Black Marble nighttime lights product suite. Remote Sensing of Environment 210: 113-143.

Ruby EG, Morin JG. 1979. Luminous enteric bacteria of marine fishes: A study of their distribution, densities, and dispersion. Appl. Environ. Microbiol. 38:406-411.

Tanet L, Tamburini C, Baumas C, Garel M, Gwénola S, Casalot L. 2019. Bacterial Bioluminescence: Light Emission in Photobacterium phosphoreum Is Not Under Quorum-Sensing Control. Frontiers in Microbiology. 10(365). 
Taufik I, Zafran, Koesharyani I, Boer D. 1996. Pemanfaatan Fitoplankton Untuk Menekan Perkembangan Bakteri Bercahaya (Vibrio harveyi). Jurnal Penelitian Perikanan Indonesia. 2(37).

Wiles S, Ferguson K, Stefanidou M, Young DB, Robertson BD. 2005. Alternative Luciferase for Monitoring Bacterial Cells under Adverse Conditions. Applied and Environmental Microbiology. 71 (7): 3427-3432.

Zarubin M, Belkin S, Ionescu M, Genin A. 2012.Bacterial bioluminescence as a lure for marine zooplankton and fish. Proceedings of the National Academy of Sciences Jan. 109(3): 853-857. 